\title{
KETERCAPAIAN KOMPETENSI LAS TIG LEVEL $1 G$ PADA PERKULIAHAN TEKNIK PENGELASAN
}

\author{
Reza C. Wijaya ${ }^{1}$ Yayat $^{2}$, Asep H. Sasmita ${ }^{3}$ \\ Departemen Pendidikan Teknik Mesin \\ Universitas Pendidikan Indonesia \\ Jl. Dr. Setiabudhi No. 207 Bandung 40154 \\ reza_chandra@rocketmail.com
}

\begin{abstract}
ABSTRAK
Tujuan penelitian ini untuk melihat tingkat ketercapaian kompetensi yang berupa hasil belajar aspek keterampilan oleh mahasiswa pada proses pengelasan Las TIG level 1G. Kompetensi tersebut yaitu: kemampuan dalam membuat rigi las tanpa bahan tambah, kemampuan dalam membuat rigi las dengan bahan tambah, kemampuan dalam membuat sambungan I dengan bahan tambah, dan kemampuan dalam membuat sambungan sudut luar dengan bahan tambah pada pelat baja lunak. Hal tersebut didasarkan pada kenyataan bahwa proses pembelajaran pada mata kuliah tersebut belum optimal akibat terbatasnya sarana dan prasarana yang dimiliki, sehingga mahasiswa harus menunggu giliran untuk melakukan latihan. Penelitian dilakukan terhadap mahasiswa yang mengontrak mata kuliah Teknik Pengelasan Tahun ajaran 2014-2015 di DPTM FPTK UPI. Metode yang digunakan adalah metode deskriptif dengan instrumen penelitian berupa pedoman wawancara dan pedoman observasi. Berdasarkan hasil penelitian diperoleh bahwa tingkat ketercapaian kompetensi yang berupa hasil belajar aspek keterampilan pada las TIG level $1 \mathrm{G}$ tegolong sedang.
\end{abstract}

Kata kunci: kompetensi, Las TIG, $1 \mathrm{G}$, rigi, baja, sambungan

\section{PENDAHULUAN}

Teknik Pengelasan di DPTM FPTK UPI bersifat perluasan pendalaman yang memiliki bobot 4 SKS, terdiri dari pengelasan Tungsten Inert Gas (TIG) dan Metal Inert Gas (MIG). Waktu yang disediakan untuk pengelasan TIG adalah 4 x 3 x 60 menit per pertemuan dan 8 pertemuan dalam satu semester atau 96 jam pembelajaran. Pengelasan TIG ini menggunakan gas pelindung, maksudnya untuk melindungi daerah las dari pengaruh gas oksigen yang ada di udara, sehingga sambungan yang dilas akan lebih mempunyai sifat-sifat komposisi kimia metalurgi dan fisik sebagaimana logam dasarnya. Pada umumnya pengelasan ini menggunakan las murni (Argon, Helium, atau campuran Argon dan Helium). Untuk lebih mudah mempelajari dan memahami perkuliahan ini harus sudah pernah mengikuti pembelajaran tentang Gambar Teknik, melakukan Proses Las Shield Metal Arc Welding (SMAW) dan Las Oxygen Acetylene Welding (OAW) serta Kesehatan dan Keselamatan Kerja (K3).

Perkuliahan Teknik Pengelasan menuntut mahasiswa memiliki kemampuan dalam menyiapkan mesin Las TIG, menyiapkan bahan untuk proses las TIG, menyiapkan bahan

\footnotetext{
${ }^{1}$ Mahasiswa Departemen Pendidikan Teknik Mesin FPTK UPI

${ }^{2}$ Dosen Departemen Pendidikan Teknik Mesin FPTK UPI

${ }^{3}$ Dosen Departemen Pendidikan Teknik Mesin FPTK UPI
} 
kawat pengisi TIG, dan melaksanakan pengelasan dengan proses Las TIG sesuai dengan Welding Procedure Specification (WPS) pada pelat baja lunak dengan posisi 1G sebagai persiapan dalam mengikuti uji kompetensi bidang pengelasan dalam las TIG level 1G. Untuk mencapai kompetensi las TIG level $1 \mathrm{G}$ mahasiswa harus menempuh proses pelatihan pada perkuliahan praktikum. Ketercapaian kompetensi melalui perkuliahan praktikum harus didukung dengan sarana dan prasarana yang memadai. Rasio dosen tetap terhadap mahasiswa 1:20, ruang praktek $2 \mathrm{~m}^{2} /$ mahasiswa, dan alat terhadap mahasiswa 1:1 untuk menunjang proses pembelajaran yang teratur dan berkelanjutan. Ketiga hal tersebut harus terpenuhi agar perkuliahan praktikum berjalan dengan baik (Rooijakkers, 2003).

Pelaksanaan perkuliahan Teknik Pengelasan, didapat suatu gambaran umum sebagai berikut: ketersediaan mesin las TIG yang terdapat di workshop produksi perancangan hanya ada 1 unit, sedangkan jumlah mahasiswa yang mengikuti perkuliahan sebanyak 10 orang. Rasio antara alat dengan mahasiswa adalah 1:10; jumlah mahasiswa yang mengontrak mata kuliah Teknik Pengelasan sebanyak 10 orang dan jumlah dosen yang bertugas mengampu mata kuliah tersebut sebanyak 1 orang. Rasio antara dosen dengan mahasiswa 1:10; ruang praktek Teknik Pengelasan yang ada di workshop produksi adalah $6 \mathrm{~m}^{2}$ untuk 10 orang mahasiswa yang mengikuti perkuliahan Teknik Pengelasan. Rasio ruang praktek dengan mahasiswa adalah 1:0,6; dan Alat Pelindung Diri (APD) yang harus digunakan mahasiswa pun masih kurang sesuai dengan standar ideal sehingga menyulitkan mahasiswa saat melaksanakan praktek.

Kondisi yang dipaparkan di atas menyebabkan proses perkuliahan menjadi kurang optimal. Banyak mahasiswa yang harus menunggu giliran melakukan latihan meskipun hanya untuk satu kali latihan. Akibatnya banyak mahasiswa yang tidak mampu menyelesaikan tugas perkuliahan sesuai waktu yang telah ditentukan. Sementara mahasiswa dituntut untuk mampu menyelesaikan tugas tepat waktu. Akibat lain yang ditimbulkan dengan kondisi seperti di atas adalah tidak optimalnya penguasaan keterampilan oleh mahasiswa dalam melakukan pengelasan dengan las TIG level 1G. Tingkat penguasaan keterampilan pengelasan las TIG dalam menyiapkan mesin las TIG, menyiapkan bahan untuk proses las TIG, dan melaksanakan pengelasan dengan proses las TIG level $1 \mathrm{G}$ masih belum optimal (George and Jones, 2005).

Ketidak sesuaian rasio sarana dan prasarana dengan jumlah mahasiswa secara tidak langsung menyiratkan bahwa dukungan sarana dan prasarana terhadap proses pembelajaran belum optimal. Proses pembelajaran khususnya pembelajaran praktik dapat dilakukan dengan optimal apabila didukung oleh adanya sarana dan prasarana yang 
memadai (Mulyasa, 2004). Dengan proses pembelajaran seperti itu, tidak menutup kemungkinan bahwa penguasaan keterampilan oleh mahasiswa menjadi tidak optimal, penguasaan keterampilan akan maksimal apabila dilakukan secara berulang-ulang (Sanjaya, 2011). Latihan yang dilakukan berulang-ulang akan memberikan pengaruh yang sangat besar pada pemahiran keterampilan.

\section{METODE PENELITIAN}

Metode yang digunakan dalam penelitian ini adalah metode penelitian deskriptif. Penelitian ini tidak menguji hipotesis melainkan hanya memaparkan keadaan suatu kondisi secara rill tanpa ada manipulasi atau campur tangan yang mempengaruhi subjek penelitian karena merupakan studi kasus. Deskripsi tersebut untuk memperlihatkan tingkat ketercapaian kompetensi Las TIG level 1G pada perkuliahan Teknik Pengelasan dan menentukan langkah yang dapat diambil dari kondisi yang terjadi dilapangan.

\section{HASIL PENELITIAN}

Berdasarkan hasil pengolahan data ketercapaian kompetensi las TIG level $1 \mathrm{G}$ pada proses membuat rigi las tanpa bahan tambah, terdapat $90 \%$ yang dinyatakan lulus. Dari 9 orang mahasiswa tersebut, sebanyak $10 \%$ lulus dengan predikat unggul, dan $80 \%$ lulus dengan predikat baik.

Pada proses membuat rigi las tanpa bahan tambah terdapat lima aspek yang harus dilakukan, yaitu: persiapan, sikap kerja, proses kerja, hasil dan waktu. Rata-rata ketercapaian kompetensi las TIG level $1 \mathrm{G}$ pada proses membuat rigi las tanpa bahan tambah (Tabel 1) berdasarkan aspeknya-aspeknya, baru mencapai 83,3\%. Ketercapaian kompetensi las TIG level $1 \mathrm{G}$ pada proses membuat rigi las dengan bahan tambah, terdapat $60 \%$ yang dinyatakan lulus. Hanya 6 orang mahasiswa tersebut, mendapatkan predikat baik (B).

Tabel 1. Kompetensi membuat rigi las tanpa bahan tambah pada pelat baja lunak

\begin{tabular}{cccc}
\hline No & Aspek & Jumlah Indikator & Tingkat Ketercapaian \\
\hline 1 & Persiapan & 10 & $73,0 \%$ \\
2 & Sikap Kerja & 6 & $83,3 \%$ \\
3 & Proses & 9 & $74,5 \%$ \\
4 & Hasil & 5 & $86,0 \%$ \\
5 & Waktu & 1 & $100 \%$ \\
& Rata-rata & $83,3 \%$ \\
\hline
\end{tabular}


Pada proses membuat rigi las dengan bahan tambah terdapat lima aspek yang harus dilakukan, yaitu: persiapan, sikap kerja, proses kerja, hasil dan waktu. Rata-rata ketercapaian kompetensi las TIG level $1 \mathrm{G}$ pada proses membuat rigi las dengan bahan tambah (Tabel 2) berdasarkan aspeknya-aspeknya, baru mencapai 80,3\%. Berdasarkan hasil pengolahan data ketercapaian kompetensi las TIG level $1 \mathrm{G}$ pada proses membuat sambungan I dengan bahan tambah, terdapat $40 \%$ yang dinyatakan lulus dengan predikat baik.

Tabel 2. Kompetensi membuat rigi las dengan bahan tambah pada pelat baja lunak

\begin{tabular}{llcc}
\hline No & Aspek & Jumlah Indikator & Pencapaian kompetensi \\
\hline 1 & Persiapan & 11 & $74,5 \%$ \\
2 & Sikap kerja & 6 & $83,3 \%$ \\
3 & Proses kerja & 10 & $69,0 \%$ \\
4 & Hasil & 6 & $74,9 \%$ \\
5 & Waktu & 1 & $100 \%$ \\
& \multicolumn{2}{r}{ Rata-rata } & $80,3 \%$ \\
\hline
\end{tabular}

Pada proses membuat sambungan I dengan bahan tambah terdapat lima aspek yang harus dilakukan, yaitu: persiapan, sikap kerja, proses kerja, hasil dan waktu. Rata-rata ketercapaian kompetensi las TIG level $1 \mathrm{G}$ pada proses membuat sambungan I dengan bahan tambah (Tabel 3) berdasarkan aspeknya-aspeknya, baru mencapai 78,2\%. Ketercapaian kompetensi las TIG level $1 \mathrm{G}$ pada proses membuat sambungan sudut luar dengan bahan tambah, terdapat 50\% yang dinyatakan lulus dengan predikat baik.

Tabel 3. Kompetensi membuat sambungan I dengan bahan tambah pada pelat baja lunak

\begin{tabular}{llcc}
\hline No & Aspek & Jumlah Indikator & Pencapaian kompetensi \\
\hline 1 & Persiapan & 11 & $74,5 \%$ \\
2 & Sikap kerja & 6 & $83,3 \%$ \\
3 & Proses kerja & 11 & $68,2 \%$ \\
4 & Hasil & 6 & $65,0 \%$ \\
5 & Waktu & 1 & $100 \%$ \\
& \multicolumn{2}{c}{ Rata-rata } & $78,2 \%$ \\
\hline
\end{tabular}

Pada proses membuat sambungan sudut luar dengan bahan tambah terdapat lima aspek yang harus dilakukan, yaitu: persiapan, sikap kerja, proses kerja, hasil dan waktu. Rata-rata ketercapaian kompetensi las TIG level $1 \mathrm{G}$ pada proses membuat sambungan sudut luar dengan bahan tambah (Tabel 4) berdasarkan aspeknya-aspeknya, baru mencapai $80,5 \%$. 
Tabel 4. Kompetensi membuat sambungan sudut luar dengan bahan tambah pada pelat baja lunak

\begin{tabular}{llcc}
\hline No & \multicolumn{1}{c}{ Aspek } & Jumlah Indikator & Pencapaian kompetensi \\
\hline 1 & Persiapan & 11 & $74,5 \%$ \\
2 & Sikap kerja & 6 & $83,3 \%$ \\
3 & Proses kerja & 11 & $60,9 \%$ \\
4 & Hasil & 8 & $83,7 \%$ \\
5 & Waktu & 1 & $100 \%$ \\
& & & $80,5 \%$ \\
\hline
\end{tabular}

\section{PEMBAHASAN}

Ketercapaian kompetensi las TIG level $1 \mathrm{G}$ pada proses membuat rigi las tanpa bahan tambah pada pelat baja lunak, dalam kategori sangat tinggi. Hal tersebut ditunjukan dengan kenyataan bahwa hanya ada 90\%yang dinyatakan lulus dengan predikat unggul (A) $10 \%$, dan predikat baik $80 \%$.

Kenyataan tersebut baru 90\%, hal itu menunjukan bahwa proses membuat rigi las tanpa bahan tambah pada pelat baja lunak masih merupakan teknik dasar pengalesan sehingga pencapaian kompetensi masih dalam kategori sangat tinggi yaitu $90 \%$ yang dinyatakan lulus. Proses ini masih memiliki pencapaian indikator yang lebih sedikit dibandingkan dengan proses pengelasan yang lainnya.

Membuat rigi las tanpa bahan tambah pada las TIG prosesnya tidak jauh berbeda pada pengelesan asetilin, sehingga pencapaian kompetensi pada proses ini sangat tinggi karena mahasiswa sudah melakukan pelatihan berulang-ulang pada saaat pengelasan asetilin. Penguasaan keterampilan hanya dapat diperoleh melalui latihan yang dilakukan secara berulang-ulang. Tetapi tingkat kesulitan pada pengelasan TIG berbeda dengan pengelesan asetylin, pengelasan TIG merupakan jenis las listrik yang menggunakan elektroda tidak terkonsumsi sebagai busur listrik, pengelasan TIG juga menggunakan gas mulia untuk mencegah oksidasi.

Proses ini berada dalam kategori sangat tinggi karena ada $90 \%$ yang dinyatakan lulus, sedangkan $10 \%$ yang dinyatakan belum lulus. Hal tersebut menggambarkan bahwa prestasi belajar mahasiswa masih belum merata. Tahapan perubahan seluruh tingkah laku individu yang relative menetap sebagai hasil pengalaman dan interaksi dengan lingkungan yang melibatkan proses kognitif (Syah, 2011). Prestasi belajar merupakan ukuran keberhasilan yang diperoleh siswa selama proses belajarnya. Keberhasilan itu ditentukan 
oleh berbagai faktor yang saling berkaitan. Faktor yang mempengaruhi prestasi belajar mencakup faktor internal dan faktor eksternal (Slameto, 2010).

Tidak meratanya prestasi belajar pada proses ini diduga berasal dari faktor internal atau faktor yang berasal dari dalam diri siswa itu sendiri. Berdasarkan hasil pengamatan, dari 10 orang mahasiswa hanya terdapat $30 \%$ yang berasal dari SMK Program Keahlian Teknik Mesin. Faktor internal yang berupa motivasi individu untuk tahapan perubahan dengan bakat yang dimiliki menentukan terhadap keberhasilan siswa. Meskipun tidak dipungkiri juga masing-masing individu memiliki potensi dan kecepatan belajar yang berbeda.

Ketercapaian kompetensi las TIG level $1 \mathrm{G}$ pada proses membuat rigi las dengan bahan tambah pada pelat baja lunak seperti pada lampiran 1, berada dalam kategori sedang. Hal tersebut ditunjukan dengan kenyataan bahwa hanya ada $60 \%$ yang dinyatakan lulus dengan predikat baik.

Kenyataan tersebut baru $60 \%$, karena proses membuat rigi las dengan bahan tambah pada pelat baja lunak pada pengelasan TIG prosesnya tidak jauh berbeda dengan pengelasan asetilin yang telah dilakukan oleh mahasiswa pada mata kuliah Pengerjaan Logam. Meskipun mahasiswa telah melakukan latihan berulang-ulang pada pengelasan asetilin, pada proses ini alat bantu dan APD sangat berpengaruh terhadap pelaksanaan praktik. Mahasiswa memiliki keterbatasan dalam melakukan praktek yang menyebabkan ketercapaian kompetensi hanya $60 \%$.

Pembelajaran adalah suatu kombinasi yang tersusun meliputi unsur-unsur manusiawi, material, fasilitas perlengkapan dan prosedur yang saling mempengaruhi mencapai tujuan pembelajaran (Hamalik, 2005). Pembelajaran berbasis kompetensi adalah pembelajaran yang dilakukan antara guru dengan peserta didik dengan tujuan untuk mencapai kompetensi. Ketercapaian kompetensi pada proses ini baru mencapai 60\%, kenyataan tersebut menggambarkan bahwa mahasiswa masih mengalami kesulitan dalam menguasai kompetensi tersebut.

Faktor dari luar merupakan faktor yang berasal dari luar pelajar yang berupa lingkungan alam dan lingkungan sosial, pengajar, sarana dan fasilitas. Faktor eksternal yaitu fasilitas yang berupa alat utama, alat bantu dan K3 masih belum ideal. Faktualnya alat utama yang berupa mesin las hanya terdapat 1 buah (rasio alat dengan mahasiswa 1:10), idealnya rasio alat dengan mahasiswa yaitu 1:1. Rasio alat dengan mahasiswa yang tidak ideal ini menyebabkan mahasiswa harus saling menunggu untuk melaksanakan praktik. Akibatnya kesempatan mahasiswa untuk berlatih menjadi terbatas. Dengan kondisi 
fasilitas seperti itu, menyebabkan latihan yang dilakukan tidak bisa secara intensif dan berulang-ulang karena hanya dapat dilakukan sebanyak satu kali kesempatan berlatih, karena harus memberikan kesempatan mahasiswa lain untuk pemerataan kesempatan. Asumsinya adalah dengan pemberian kesempatan latihan yang sama, pencapaian kompetensi yang diperoleh juga relative sama (Syaiful, 2011). Meskipun tidak dipungkiri juga masing-masing individu memiliki potensi dan kecepatan belajar yang berbeda. Fasilitas berupa alat K3 yang tidak ideal, misalnya sarung tangan yang digunakan tidak lentur, menyebabkan kesulitan mahasiswa saat praktik. Terbatasnya jumlah topeng las khusus TIG yang dimiliki (1 buah), menyebabkan mahasiswa harus bergantian untuk menggunakan alat tersebut, sehingga menyebabkan mahasiswa sulit untuk melihat secara langsung, pada saat dosen memberikan contoh proses pengelasan.

Faktor internal yang terlihat pada penguasaan materi yang dimiliki mahasiswa untuk aspek proses kerja yang pencapaian indikatornya tidak maksimal menyebabkan ketercapaian kompetensi rendah. Faktual lainnya mahasiswa masih belum memahami pentingnya kesehatan dan keselamatan kerja, hal tersebut dilihat karena adanya mahasiswa yang belum menggunakan safety shoes saat melakukan praktik.

Ketercapaian kompetensi las TIG level $1 \mathrm{G}$ pada proses membuat sambungan I dengan bahan tambah pada pelat baja lunak seperti pada lampiran 1, berada dalam kategori rendah. Hal tersebut ditunjukan dengan kenyataan bahwa hanya ada $40 \%$ yang dinyatakan lulus dengan predikat baik. kenyataan tersebut menggambarkan bahwa mahasiswa masih mengalami kesulitan dalam menguasai kompetensi tersebut.

Kenyataan tersebut baru $40 \%$ karena proses membuat sambungan I dengan bahan tambah pada pelat baja lunak sudah memiliki pencapaian indikator yang banyak dibandingkan dengan proses sebelumnya. Faktor yang mempengaruhi prestasi belajar adalah faktor dari luar dan faktor dari dalam (Purwanto, 2006). Faktor dari luar dan faktor dari dalam yang mempengaruhi prestasi belajar itu adalah faktor dari luar (eksternal), merupakan faktor yang berasal dari luar pelajar (siswa) yang meliputi: lingkungan alam dan lingkungan social, instrumentasi yang berupa kurikulum, guru atau pengajar, sarana dan prasarana. Faktor dari dalam (internal), merupakan faktor yang berasal dalam diri pelajar (siswa) itu sendiri yang meliputi: fisiologi yang berupa kondisi fisik dan kondisi panca indra dan psikologi yang berupa bakat, minat, kecerdasan, motivasi dan kemampuan kognitif (Syaiful, 2011).

Sarana dan prasarana faktualnya masih belum sesuai dengan standar ideal, menyebabkan mahasiswa tidak mampu melakukan pembelajaran dengan maksimal. Rasio 
mesin las (alat utama) dengan mahasiswa sebesar 1:10 dan rasio APD dengan mahasiswa sebesar 1:10, menjadi salah satu penyebabnya, karena idealnya rasio antara alat dengan mahasiswa adalah 1:1. Dengan rasio tersebut, menyebabkan mahasiswa harus saling menunggu untuk melaksanakan praktik pengelasan, akibatnya kesempatan untuk praktik menjadi terbatas. Penguasaan keterampilan hanya dapat diperoleh melalui latihan yang dilakukan secara berulang-ulang. Adapun terjadinya fenomena antrian setidaknya mengindikasikan kesempatan yang dimiliki oleh mahasiswa berkurang dan tidak merata, karena harus saling tunggu menunggu untuk mendapatkan giliran melaksanakan latihan. Latihan yang dilakukan tidak bisa secara intensif dan berulang-ulang dan hanya dapat dilakukan sebanyak satu kali kesempatan berlatih karena harus memberikan kesempatan mahasiswa lain untuk pemerataan kesempatan. Hal tersebut karena sarana dan prasarana yang belum ideal. Ketidak sesuaian sarana dan prasarana secara tidak langsung menyiratkan dengan kondisi yang seperti demikian belum dapat menunjang proses pembelajaran secara maksimal.

Faktor internal terlihat pada penguasaan materi yang dimiliki mahasiswa pada aspek proses kerja yang pencapaian indikatornya tidak maksimal menyebabkan ketercapaian kompetensi rendah. Faktual lainnya mahasiswa masih belum memahami pentingnya kesehatan dan keselamatan kerja, hal tersebut dilihat karena adanya mahasiswa yang belum menggunakan safety shoes saat melakukan praktik. Latihan yang dilakukan tidak bisa secara intensif dan berulang-ulang dan hanya dapat dilakukan sebanyak satu kali kesempatan berlatih karena harus memberikan kesempatan mahasiswa lain untuk pemerataan kesmpatan. Asumsinya adalah dengan pemberian kesempatan latihan yang sama, pencapaian kompetensi yang diperoleh juga relatif akan sama (Palan, 2007). Meskipun tidak dipungkiri juga masing-masing individu memiliki potensi dan kecepatan belajar yang berbeda.

Ketercapaian kompetensi las TIG level $1 \mathrm{G}$ pada proses membuat sambungan sudut luar dengan bahan tambah pada pelat baja lunak seperti pada lampiran 1, berada dalam kategori sedang. Hal tersebut ditunjukan dengan kenyataan bahwa hanya ada $50 \%$ yang dinyatakan lulus dengan predikat baik (B). Kenyataan tersebut baru 50\%, hal ini menyatakan bahwa proses membuat sambungan sudut luar dengan bahan tambah pada pelat baja lunak memiliki pencapaian indikator yang paling banyak dibandingkan dengan proses lainnya. Ketercapaian kompetensi pada proses ini sedang, hal tersebut terjadi masih sama dikarenakan sarana dan prasarana yang belum ideal, penguasaan materi mahasiswa masih belum maksimal. 
Ketidak sesuaian sarana dan prasarana secara tidak langsung menyiratkan dengan kondisi yang seperti demikian belum dapat menunjang proses pembelajaran secara maksimal. Rasio mesin las dengan mahasiswa yaitu 1:10 menyebabkan mahasiswa harus saling menunggu untuk melaksanakan praktik pengelasan. APD yang terdapat di workshop produksi dan perancangan masih tidak sesuai dengan standar ideal pengelasan TIG.

Selain dari faktor sarana dan prasarana, proses pelaksanaan praktik las TIG dapat mempengaruhi ketercapaian kompetensi. Adapun terjadinya fenomena antrian setidaknya mengindikasikan kesempatan yang dimiliki oleh mahasiswa berkurang dan tidak merata, karena harus saling tunggu menunggu untuk mendapatkan giliran melaksanakan latihan. Latihan yang dilakukan tidak bisa secara intensif dan berulang-ulang dan hanya dapat dilakukan sebanyak satu kali kesempatan berlatih karena harus memberikan kesempatan mahasiswa lain untuk pemerataan kesmpatan. Asumsinya adalah dengan pemberian kesempatan latihan yang sama, pencapaian kompetensi yang diperoleh juga relatif akan sama. Meskipun tidak dipungkiri juga masing-masing individu memiliki potensi dan kecepatan belajar yang berbeda (Muslich, 2011).

Ketercapaian kompetensi dapat dipengaruhi dosen pengampu mata kuliah Teknik Pengelasan yang belum memiliki sertifikat pengelasan TIG. Hal tersebut tidak menjamin keberlangsungan kegiatan pembelajaran Teknik Pengelasan sesuai dengan apa yang diharapkan. Walaupun menurut standar untuk rasio ideal antara dosen dengan mahasiswa adalah 1:25. Namun dengan karakteristik pembelajaran mata kuliah Teknik Pengelasan memiliki tempat praktik yang berbeda antara las TIG dan MIG menyulitkan dosen dalam pelaksanaan pengawasannya.

\section{KESIMPULAN}

Kesimpulan penelitian ini sebagai berikut: ketercapaian kompetensi Las TIG level $1 \mathrm{G}$ pada proses membuat rigi las tanpa bahan tambah pada pelat baja lunak dalam kategori sangat tinggi. Ketercapaian kompetensi Las TIG level $1 \mathrm{G}$ pada proses membuat rigi las dengan bahan tambah pada pelat baja lunak dalam kategori sedang. Ketercapaian kompetensi Las TIG level $1 \mathrm{G}$ pada proses membuat sambungan I dengan bahan tambah pada pelat baja lunak dalam kategori rendah. Ketercapaian kompetensi Las TIG level 1G pada proses membuat sambungan sudut luar dengan bahan tambah pada pelat baja lunak dalam kategori sedang. Kesimpulan bahwa ketercapaian kompetensi hasil belajar aspek keterampilan pada kompetensi las TIG level $1 \mathrm{G}$ berada dalam kategori sedang. 


\section{DAFTAR PUSTAKA}

Dimyati dan Mudjiono. (2002). Belajar dan Pembelajaran. Jakarta: Departemen Pendidikan dan Kebudayaan.

George dan Jones. (2005). Understanding and Managing Organizational Behaviour 4 Edition. Pearson. Prentice Hall.

Hamalik, O. (2005). Proses Belajar Mengajar. Jakarta: Bumi Aksara.

Syah, M. (2004). Psikologi Pendidikan dengan Pendekatan Baru. Bandung: PT. Remaja Rosda Karya.

Muslich, M. (2011). KTSP Pembelajaran Berbasis Kompetensi dan Kontekstual. Jakarta: Bumi Aksara.

Mulyasa. (2004). Kurikulum Berbasis Kompetensi: Konsep, Karakteristik dan Implementasi. Bandung: PT. Remaja Rosdakarya.

Purwanto, N. (2006). Psikologi Pendidikan. Bandung: PT. Remaja Rosda Karya.

Palan, R. (2007). Competency Management. Teknik Mengimplementasikan Manajemen SDM Berbasis Kompetensi Untuk Meningkatkan Daya Saing Organisasi. Penerjemah:Octa Melia Jalal. Jakarta: PPM.

Rooijakkers, A.D. (2003). Mengajar Dengan Sukses Petunjuk Merencanakan dan Menyampaikan Pengajaran. Jakarta: Grasindo.

Sanjaya, W. (2011). Pembelajaran dalam Implementasi Kurikulum Berbasis Kompetensi. Jakarta: Kencana.

Slameto. (2010). Belajar dan Faktor-Faktor yang Mempengaruhinya. Jakarta: PT Rineka Cipta.

Syaiful, B. (2011). Psikologi Belajar. Jakarta: Rineka Cipta. 